\title{
Environmental principles for planting of greenery in settlements of Baikal Siberia
}

\author{
Oksana Vinkovskaya ${ }^{1, *}$ and Eduard Enin $^{1}$ \\ ${ }^{1}$ Irkutsk State Agrarian University named after A.A. Ezhevsky, Molodezhny township, 1/1, Irkutsk \\ region, 664038, Russia
}

\begin{abstract}
Based on the publications analysis and our own research, the ecological principles are considered, which should form the basis of longterm plans for planting of greenery in settlements in Baikal Siberia and take into account important regional features. The research was conducted using methods of information collection and analysis, which include comparison and systematization of data on the indicated problem. The current general urban plans of towns, which are in open access, as well as urban planning standards for the allocation of functional zones of settlements were studied. The influence of the urban environment on the existence of plants is examined. The problem of invasion of cultivated species as a result of unreasoned planting of greenery and the need to use indigenous species for amenity planting, especially those that are rare and in need of protection, were identified. The conclusion was made that when planting of greenery, one should take into account the florogenetic and phytocoenotic properties of the vegetation cover of the studied territory. Environmental principles of planting of greenery in settlements of Baikal Siberia are proposed as conceptual. Keywords: amenity planting, urban infrastructure, Cisbaikalia, Transbaikalia.
\end{abstract}

\section{Introduction}

The problem of urbanization in its basic tenets was formed back in the last century, and now its solution has a huge environmental acuteness. The transformation of natural processes associated with urbanization is manifested primarily at the local and regional levels and it is also rapidly gaining a global scale throughout the biosphere [1]. Tracking changes in ecosystem parameters, including biodiversity indicators, is of course important for all areas, but priority is given primarily to those regions that include high conservation value objects.

Baikal Siberia (BS), the organizing center of which is Lake Baikal - the World Heritage Site, has an area of 1,551,100 km2 and includes three large subjects of the Russian Federation (Irkutsk Region, Republic of Buryatia, Trans-Baikal Territory). From a geographical point of view, they are understood as Cisbaikalia, Western Transbaikalia and Eastern Transbaikalia, which territories relate to the catchment area of Lake Baikal, as well as with the zones of atmospheric influence on it.

${ }^{*}$ Corresponding author: urbanoflora@yandex.ru 
BS does not belong to the most populated regions of the Russian Federation, and, moreover, of the world, but its natural resource wealth and unique biodiversity determine a special environmental responsibility and the need to pay close attention to all aspects of economic activity and natural management.

The process of global urbanization is currently unstoppable, and the theoretical and empirical solution to the problems associated with it is seen primarily in the creation of Green Cities [2]. However, this is in the future.

The criteria of Green Cities can and should be applied to small settlements, which may have to be transformed into cities. Optimization of the environmental conditions of already existing large settlements (cities and urban-type settlements) both in terms of favorable human existence and as a way to minimize the impact of urbanization on the biosphere is recognized and traditionally associated with the qualitative and quantitative characteristics of green infrastructure, as well as with rational urban planning, which includes effective greening. Urban greening and all its aspects have indeed become the subject of the most thorough and multifaceted research by the world scientific community, which recognizes the environmental priority and urgency of the problem.

Planting of greenery in settlements always has strict regional features and does not imply uniform approaches in the territorial distribution of green areas or qualitative selection of plant species. It is necessary to take into account a whole complex of factors, including climatic conditions, soil-ground, hydrological, etc., including urban planning, ethnic, socio-economic, historical, etc. features of the territory. At the same time, the requirements and fundamental principles that should be applied to green infrastructure should be developed and used to assess its effectiveness.

In this regard, the purpose of this scientific paper was to identify and outline the environmental principles that, in our opinion, should form the basis of long-term plans for planting of greenery in BS settlements and consider important regional features.

\section{Materials and Methods}

The research was conducted using methods of information collection and analysis, which include comparison and systematization of data on the indicated problem. The current general urban plans of BS towns, which are in open access, as well as urban planning standards of the Russian Federation on the allocation of functional zones of settlements were studied. The zoning of the city of Irkutsk as the largest settlement of the BS, the territory of which includes the most presentable range of functional zones, is taken as a general scheme.

Theoretical and applied aspects of green infrastructure development in the world's cities were analyzed. At the same time, the list of references included a small part of sources, the data from which influenced the environmental principles developed by us, proposed as a basis for long-term concepts in the greening of settlements of the study area.

The recommendations on creating sustainable urban design strategies [2, 3], studies on the need for (or lack thereof) area-based expression of green spaces per capita [4, 5] and approaches to land use planning through a conceptual model [6] were taken into account.

The regional applicability of the international trend of urban greening has been studied [7], regulatory problems in the practice of green infrastructure regulation [8], review of spatial planning for environmental protection in the countries of the Organization for Economic Cooperation and Development [9], revaluation of the forms and functions of greening in terms of their contribution to urban sustainability of the compact city model [10].

The experience of using arboreal plants of different geographical origin and differentiation of species composition for ecologically functional groups of planting 
objects, the aspects of correct choice of trees [11], including representatives of specific systematic groups [12], as well as the studies on the perception and preference of green infrastructure objects [13], the demand for collective urban gardens [14], the importance of urban green spaces in maintaining physical activity [15], social interaction and, in general, comfortable emotional state of population [16] were analyzed.

We have taken a note of the climate-forming and climate-regulating functions of green spaces $[17,18]$ and their ability to qualitatively affect the ecological conditions of the city $[1,19,20]$, accompanied by changes in vegetation phenology and the increase of the growing period in urban conditions [21]. Also we have taken into account the methodological methods of research on urbanization of territories [22], recommendations and guidelines for assessing green infrastructure [23], mechanisms for increasing the ecological efficiency of cities through the development of the industrial structure [24], including electricity [25], the development of public-private partnerships to create infrastructure of urbanized areas [26].

The peculiarities of BS urbanization have been identified from the public access sources, archival materials, publications [27] and primary observations.

\section{Results and Discussion}

BS is located almost in the center of Asia and it borders with Outer Mongolia, the Far East and Northern China, and fulfils the function of a boundary in both physical-geographical and biogeographic relations. The climatic conditions of the BS territory fully depend on its position in temperate latitudes (between 48 and $64^{\circ} \mathrm{N}$ ). Determining factors of climate formation are radiation regime and circulation features of the atmosphere, which are associated with the remoteness from the seacoasts and the local influence of water masses of Lake Baikal, mountain relief and intracontinental geographic location. In the main features the BS climate is characterized as continental (with variations from moderately continental in Cisbaikalia to sharply continental in Transbaikalia and ultra-continental in deep basins of Northern Trans-Baikal region), with long cold winters with little snow, short droughty and windy spring, hot and humid in its second half summer, with cool and clear autumn.

The vegetation cover of BS is formed from various elements of floristic and phytocentric complexes of various origin and age. It should be noted that BS is a key territory in the migration processes of living in Asia organisms, and for many species it is locus classicus.

The development of the BS, accompanied by the appearance of the very first cities (primarily Irkutsk, Ulan-Ude, Chita and some other settlements), began in the second half of the XVII century. At the first stages, the process of urbanization did not have serious manifestations, which were later determined by the development of gold deposits along the tributaries of the Lena River in the XVIII century, the construction of the Trans-Siberian railway in the XIX century and the formation of the major industrial centers associated with the extraction of coal, table salt, iron ores and other minerals.

The most large-scale processes began in the middle of XX century [27], when the main water reservoirs were created, the largest hydroelectric power plants were built and, as a result, the hydrological regime of huge territories was changed. This period is associated with a second wave of urbanization of BS, the emergence of new towns (such as Bratsk, Angarsk, Shelekhov, Baikalsk, etc.) and large industrial centers around them (more precisely, the towns around the large industrial facilities, which often occupied an almost central position). 
At present, there are 38 cities and 95 urban-type settlements (Tab. 1) with a population of 4436.8 thousand people. The number of nationalities is at least 100 , the average population density is about 2.8 and the average share of urban population is $68.5 \%$.

Table 1. Indicators of area size, quantity and quality of population in the regions of Baikal Siberia.

\begin{tabular}{|l|c|c|c|}
\hline \multicolumn{1}{|c|}{ Indicators } & Irkutsk Region & $\begin{array}{c}\text { Republic of } \\
\text { Buryatia }\end{array}$ & $\begin{array}{c}\text { Trans-Baikal } \\
\text { Territory }\end{array}$ \\
\hline Area size, thous. km ${ }^{2}$ & 767.9 & 351.3 & 431.9 \\
\hline Population base, thous. people & 2391.2 & 985.9 & 1059.7 \\
\hline Population density, pax/km ${ }^{2}$ & 3.1 & 2.8 & 2.4 \\
\hline Number of nationalities * & 37 & 27 & 41 \\
\hline Number of towns & 22 & 6 & 10 \\
\hline Number of urban settlements & 46 & 12 & 37 \\
\hline Rate of urban population, \% & 78.1 & 59.2 & 68.2 \\
\hline
\end{tabular}

* Note: indicated for nationalities with a rate of more than $0.01 \%$ of the total population.

The special features of urbanization in Siberia are manifested in the fact that at present towns and urban-type settlements occupy large areas and fail to meet the requirements of a compact settlement [10]. The towns are characterized by a complex combination of residential and business development, agricultural land, forests, industrial facilities and special-purpose facilities, etc.

The classic division of urbanized space into residential, industrial and recreational zones fail to meet the current reality. In view of this, on the general urban plans of large settlements of BS one can count 13 functional zones (Tab. 2), the difference in purpose and description for most of which is difficult to catch. The uniqueness in definition and purpose refers only to the zone of agricultural purpose, forests, recreation, cemeteries and water areas. Water areas are highlighted as a separate zone since they are under the responsibility of the federal level and the powers of municipalities do not apply to them.

Table 2. Functional zones of large settlements of Baikal Siberia.

\begin{tabular}{|c|c|c|}
\hline № & Type of the zone & Purpose and description of the zone \\
\hline 1. & residential zone & $\begin{array}{l}\text { for the location and functioning of already existing } \\
\text { residential buildings, as well as social facilities and } \\
\text { amenities, public health facilities, general education } \\
\text { facilities, parking lots, garages }\end{array}$ \\
\hline 2. & $\begin{array}{l}\text { zone of mixed and public- } \\
\text { business development }\end{array}$ & $\begin{array}{l}\text { for the location and functioning of already existing } \\
\text { residential buildings and other objects included in the } \\
\text { residential zone, as well as institutions of business, financial } \\
\text { and social activities (offices, shopping centers, hotels, } \\
\text { educational and research institutions), including safe utilities } \\
\text { and industrial enterprises, the placement of which is allowed } \\
\text { in the residential zones }\end{array}$ \\
\hline 3. & $\begin{array}{l}\text { multifunctional public and } \\
\text { business zone }\end{array}$ & $\begin{array}{l}\text { for the location and functioning of already existing public } \\
\text { health facilities, culture, trade, public catering, social and } \\
\text { communal services, business activities, educational facilities, } \\
\text { administrative, research institutions, parking lots, i.e. } \\
\text { facilities related to business and financial activity, as well as } \\
\text { supporting the life activities of people, including residential } \\
\text { buildings, hotels, underground and ground 1-2-storey garages }\end{array}$ \\
\hline 4. & $\begin{array}{c}\text { zone of specialized public } \\
\text { development }\end{array}$ & $\begin{array}{l}\text { for the location and functioning of already existing } \\
\text { administrative, medical, scientific, educational, trade } \\
\text { (including fairs, clothing markets), exhibition, sports and } \\
\text { other facilities that form urban competence centers for } \\
\text { general visiting. }\end{array}$ \\
\hline 5. & zone of historic development & the territory within the boundaries of settlements, including \\
\hline
\end{tabular}




\begin{tabular}{|c|c|c|}
\hline & & $\begin{array}{l}\text { buildings that appeared before the middle of XX century, } \\
\text { which are of cultural and historical value; subject to be } \\
\text { agreed by the regional authorities for protection of cultural } \\
\text { heritage objects }\end{array}$ \\
\hline 6. & $\begin{array}{l}\text { industrial zone, zone of } \\
\text { engineering and transport } \\
\text { infrastructure }\end{array}$ & $\begin{array}{l}\text { for the location and functioning of already existing industrial, } \\
\text { communal and storage facilities, power supply facilities, } \\
\text { water supply, sewerage and discharge treatment, gas supply, } \\
\text { heat supply, as well as railway, road, river, air and pipeline } \\
\text { transport, communications, engineering equipment }\end{array}$ \\
\hline 7. & agricultural zone & $\begin{array}{l}\text { for the location and functioning of already existing } \\
\text { agricultural lands (arable lands, hayfields, pastures, orchards, } \\
\text { etc.) and objects of agricultural purpose intended for } \\
\text { agricultural activities }\end{array}$ \\
\hline 8. & recreational zone & $\begin{array}{l}\text { for the location and functioning of already existing recreation } \\
\text { centers, boarding houses, camping sites, tourist bases, } \\
\text { educational and tourist trails, etc.; i.e. the territory within the } \\
\text { boundaries of settlements, intended and used for the } \\
\text { organization of long-term recreation and tourism, physical, } \\
\text { health and sport activities }\end{array}$ \\
\hline 9. & recreational open space zone & $\begin{array}{l}\text { the territory within settlements, specially organized and } \\
\text { landscaped for short-term recreation of the population } \\
\text { (squares, parks, city gardens, etc.) }\end{array}$ \\
\hline 10. & forest zone & $\begin{array}{l}\text { the territory within settlements occupied by forest (urban } \\
\text { forest zone) }\end{array}$ \\
\hline 11. & cemetery zone & $\begin{array}{l}\text { the territory within settlements occupied by existing (open } \\
\text { for burial) cemeteries and closed for the preservation period, } \\
\text { as well as for the location of new city cemeteries }\end{array}$ \\
\hline 12. & restricted zone & $\begin{array}{l}\text { for the location and functioning of already existing military } \\
\text { bases, campuses, training grounds, airfields and other } \\
\text { security and space support facilities, as well as military } \\
\text { educational institutions, enterprises and organizations of } \\
\text { federal executive authorities performing tasks in defense, } \\
\text { security and space support }\end{array}$ \\
\hline 13. & defined water zone & $\begin{array}{l}\text { the territory within settlements occupied by natural and } \\
\text { artificial (water reservoirs) surface waters }\end{array}$ \\
\hline
\end{tabular}

In the vicinity of large settlements there is a zone of private garden plots (land allotment, often $600 \mathrm{~m}^{2}$ in size, with low-rise suburban-type buildings), which are called "dacha" in Russia. Garden plots occupy significant spaces (about $100 \mathrm{~km}$ within a radius of the city) and from the point of view of rational environmental management belong to the inefficient territories. The possession of dacha for the population of Siberia and, in general, Russia, is a socio-cultural necessity, which is important from the point of view of psychological and emotional comfort, as well as a subsidiary farm for obtaining agricultural products. A similar request was identified among the population of other countries, for example, Serbia [14].

In general, the urban environment and the process of urbanization itself is ambiguous in its impact on plants and their conditions of existence. It would be wrong to point out only negative aspects [19]. The warming effect of urban communications and residential buildings on the climate of the city, the creation of artificial reservoirs, eutrophication of soil, large populations of synanthropic birds that contribute to the spread of fruits and seeds, and a number of other factors can mitigate or even compensate for the harmful effects of strong anthropogenic and man-made loads, air pollution, sharp temperature fluctuations, freezing of soil to a significant depth due to snow removal and removal of fallen leaves, etc. 
The urban influence increases the heterogeneity (variability) of ecological conditions of the environment, which inevitably improves the buffer role of coenotic connections, which are especially strong in unbroken natural phytocoenosis. In this regard, relict, endemic, rare (due to their cenophobic or complex developmental biology) plants often appear on the periphery and in the vicinity of towns. Moderating anthropogenic loads becomes an important factor of their existence in the study area. Russian botanist N.G. Ilminskikh (1998) called this phenomenon the ecotonic effect and the phenomenon of urbanogenic floristic anomaly, which increase from the center to the periphery of the town, and we have shown it as applied to Irkutsk. A change in the phenology and lengthening of the vegetation period of plants in urban conditions in comparison with the surrounding space was also noted [21], which, according to our observations, is also true for large settlements of BS.

According to our opinion and other researchers' point of view, the ecological framework of the green infrastructure of cities is composed of arboreal (trees, shrubs, lianas) and semi-shrub plants. In planting of greenery in BS towns there are at least 120 species of arboreal and semi- shrub plants, only $10 \%$ of which are widely used. In general, we estimate the range of species as poor. About $40 \%$ of the species are non-native and they appeared at the territory due to their introduction into culture. Some cultivars have been successfully naturalized and are beginning to be introduced into the composition of transformed phytocenoses, for example, into the undergrowth of urban and suburban forests of varying degrees of disturbance, along river channels, where large populations of frugivorous bird species are concentrated, confined to suburban areas, and their dispersal occurs along the secondary, man-made habitats (roadsides, wastelands, embankments, etc.). For the territory under study, there is a remarkable introduction of Amelanchier spicata (Lam) K. Koch, Grossularia reclinatum L., Cerasus fruticosa Pall., C. tomentosa (Thunb.) Wall., Crataegus pinnatifida Bunge, Padus maakii (Rupr.) Kom. \& Aliess., Rubus crataegifolius Bunge, Elaeagnus argentea Pursh, Hippophaë rhamnoides L., Lonicera tatarica L., Rhamnus cathartica L. The North American species Acer negundo L. shows the greatest activity in dispersal, which has formed entire groves in abandoned places in the last decade. The invasion of non-native cultivars was the result of unreasoned planting of greenery.

The rich gene pool of native flora of BS should become the basis for greening settlements, since local species are maximally adapted to the climatic features of the territory, and therefore are effective in maintaining the ecological and sanitary functions of plantings. Cultivation of rare for BS species (such as Viburnum opulus L., Daphne mezereum L., Cotoneaster integerrimus Medik., C. lucidus Schltdl., C. neopopovii Czerep., Atragene ochotensis Pall., Berberis sibirica Pall., Lonicera edulis Turcz. ex Freyn, Rhododendron aureum Georgi, Ephedra dahurica Turcz., Chosenia arbutifolia (Pall.) A. K. Skvortsov and many others) will support the gene pool of populations and will be an additional positive factor in their protection. Perhaps, in the future, it will ensure that they are not included in the lists of species to be protected.

A significant part of arboreal plants are excellent melliferous plants, valuable alimental and fodder plants, determine the nesting and protective properties of plantings, therefore, the increase of their number in plantings will support the existence of many animals, such as insects (bees, bumblebees, etc.), frugivorous bird species, etc.

At the time of the Union of Soviet Socialist Republics (USSR), one of the cheapest and most effective types of arboreal plants for greening was poplar (Populus sibirica G. V. Krylov et Grig. ex A. K. Skvortsov), which was called an urban vacuum cleaner. Poplar plantings were created around large industrial facilities and were effective. The poplar has a monopodial branching type and grows up to $30 \mathrm{~m}$ or more. When the wind regime intensifies, tree branches may break off and trunks may fall, which threatens the safety of the population. During the breeding season (in June), poplars produce fluff in huge 
quantities, and the inhabitants also do not like it. Therefore, poplars are subjected to harsh pruning, which devalues their ecological properties. It would be unwise to completely abandon the use of poplars in planting of greenery, but they should be planted in industrial areas far from the places of active visiting.

In dense residential development zones, the function of poplars could be replaced by arboreal plants with a sympodial branching type, for example, willows (representatives of the genus Salix), there are at least 50 species of which at the study territory, including endemic and hemiendemic ( $S$. alexii-skvortzovii A.P. Khokhr., S. alaxensis (Andersson) Coville, S. dshugdshurica A.K. Skvortsov, S. nasarovii A.K. Skvortsov, S. sajanensis Nasarow, etc.). BS is considered a part of their speciation area, however, willows are used poorly in planting of greenery. Similar recommendations were made by researchers from China [12].

All functional zones of settlements should have their own principles for greening and green infrastructure development, possibly even of water areas in the future. During the Soviet era, elements of green infrastructure were created on agricultural land on a compulsory basis - forest shelterbelt, which had the most important environmental functions of precipitation interception, mitigating the effects of strong winds, soil protection and even improving their fertility. Where possible, when land was allocated for agricultural purposes, strips of original forest were simply left, or they were created as linear plantings along the edge of fields. Poplars were mainly used, less often Betula pendula Roth, a as a soil improving component - Caragana arborescens Lam. Nowadays, there are still partially functioning forest protection strips, but there is a process of their rapid degradation, which is associated with the transfer of agricultural land to private ownership, the need for sufficiently large financial investments and lack of motivation to create.

In our opinion, certain exceptions in planting of greenery should apply only to the urban forest area, which should be kept in their original form for as long as possible and care measures should be developed for this purpose. Due to the current climatic conditions, the BS forests have a high fire hazard class, as they are formed mainly by light coniferous tree species - larch and pine (Larix dahurica Laws, L. sibirica Ledeb., Pinus sylvestris L.).

BS forests can spontaneously burn at high temperatures and low atmospheric humidity, especially from mid-April to the end of June. In recent years, the problem of forest fires has been especially acute, therefore, in order to protect the population, a recommendation has been developed to form a 30-meter-wide safety strip by means of total cutting and cleaning from grassy vegetation. Urban forest zones often have a small area and cutting them down along the entire perimeter of adjoining functional zones of other purposes will lead to reducing the area and inevitable weakening. The safety of people is more important. We see the solution to this conflict in the need to study the spontaneous combustion of various types of BS forest, the development of cultigenic phytocenoses of reduced highlands and their creation at the edge of urban forests. The use of willows would also be a solution. Perhaps then the safety belt could be reduced.

According to Russian sanitary standards, there should be at least $10 \mathrm{~m}^{2}$ of green space per inhabitant, and 10-20 $\mathrm{m}^{2}$ for regions with a short growing season, including BS. So far, this is the only quantitative indicator that can reflect the state of green urban infrastructure. In recent years, it is quite justified in our opinion that urban forests were excluded from its calculation, which obliged municipalities to increase the area of green spaces in other functional zones. For example, in Romania, the standard area of green spaces per capita is $26 \mathrm{~m}^{2}$ [4]. The effectiveness of green infrastructure should be assessed by qualitative and quantitative indicators. Qualitative indicators need to be developed while they are reduced to the species composition of plants.

In our opinion, it is important to consider the extent of its anthropogenic changes when developing greening of specific functional zones that have such a complex picture of the 
urbanized environment. In fact, the entire territory of the city from this point of view is divided into areas with completely destroyed original vegetation, areas with highly or moderately transformed original vegetation, and areas with poorly transformed original vegetation.

It is necessary to use non-native plant species in plantings only in areas with destroyed vegetation, and plantings should be isolated from natural phytocenoses in order to avoid undesirable invasion. Here you can also use the entire set of tools and a range of forms of green construction (greening of roofs, walls using containers, etc.), create masterpieces of topiary art for the delight of people and to attract tourists.

Planting of greenery is also important from the point of view of educational work in the environmental education of schoolchildren and students. In the perspective of ornithological, botanical and other types of ecotourism development, they should have an original, aboriginal, Siberian appearance, provide tourist attractiveness, and not have the character of unified planting due to the species promoted in gardening.

The ethnic composition of the BS population is very diverse. Every nation has its favorite, sacred, totemic plants, this was missed when planting of greenery in cities. This issue requires detailed study, as it is important to maintain a positive psychoemotional state of the population and as a new direction in planting of greenery.

In areas with severely and average disturbed vegetation it is possible to restore the original natural complexes without the introduction of non-native plant species. In conservation of biogeocenotic heterogeneity of natural landscapes it is necessary to have a maximum range of aboriginal species. Urban plantations should be located with the maximum use of existing vegetation and water reservoirs in such a way as to create a single system with green corridors and adjoining territories.

Within a mater of an ecological condition of urbanized space optimization, all categories of plantations should as much as possible correspond to the ecosystem approach and the following requirements: have wind, dust and noise protective properties, moisture and heat control, soil-protective, water-protective, sanitary and hygienic and, of course, decorative aesthetic. When reconstructing natural territories (suburban forests, etc.) and creating plantings, it is necessary to remember that the territory of the BS belongs to the zone of environmental supervision. Suburban forests should perform a buffer function in protecting the natural site of World Heritage - Lake Baikal.

Efficient planting of greenery in urban infrastructure is not cheap. But, as the work of domestic and foreign researchers shows, the solution to this problem is also possible [13, $23,26]$. Residents are ready to pay for improving the quality of the urban environment and its aesthetics.

\section{Conclusions}

Ecological principles for planting greenery in the settlements at the territory of the research should take into account its natural and climatic conditions, flora and phytocenogenetic features of the vegetation cover, as well as satisfy decorative and aesthetic, cognitive, historical and cultural interests of both the local population and tourists. In order to develop long-term planting of greenery plans, the following principles should be underlying:

- identify and preserve the areas with maximum expression of the ecotonic effect and the phenomenon of urban floristic anomaly;

- form a framework of greenery based on aboriginal species of arboreal and semi- shrub plants;

- it is mandatory to include species, which are endangered and on the verge of extinction for their genetic conservation; 
- for amenity planting use melliferous, valuable alimental, forage species and species that provide nest-friendly conditions and other qualities of the environment for the animal populations preservation;

- use species that have sacred and totemic significance for representatives of different nationalities;

- use species with monopodial branching for planting of greenery in industrial areas and at a distance from the places of active visit, species with sympodial branching (species of the genus Salix) for zones with residential development;

- restore the practice of creating forest shelter belts on agricultural lands;

- work out the issue of the possibility of creating cultigenic phytocenoses of low fire rate along the edge of urban forests for the purpose of their and population fire safety;

- maintain quantitative indicators of the area of green spaces per capita;

- consider the degree of anthropogenic changes in zones when developing greenery;

- when developing urban planting of greenery, consider the buffer effect of plantations and urban forests on the ecosystem of Lake Baikal.

\section{References}

1. A. Svirejeva-Hopkins, Encyclopedia of Biodiversity (Second Edition), 4, 209-218 (2019) doi: 10.1016/B978-0-12-409548-9.11178-9

2. M.-L. Tîrlă, G. Manea, I. Vijulie, E. Matei, O. Cocoş, Cities in the globalizing worlds and Turkey: a theoretical and empirical perspective, 462-479 (2014) doi: $10.13140 / 2.1 .4143 .6487$

3. K. Alawadi, Cities, 60, 353-366 (2017) doi: 10.1016/j.cities.2016.10.012

4. D. L. Badiu, C. Ioja, M. Patroescu, J. Breuste, Ecological Indicators, 70, 53-66 (2016) doi: 10.1016/j.ecolind.2016.05.044

5. D. L. Badiu, D. A. Onose, M. R. Nita, R. Lafortezza, Landscape \& Urban planning, 187, 156-164 (2018) doi: 10.1016/j.landurbplan.2018.07.015

6. A. P. Shastri, R. P. Narwade, K. Nagarajan, IJARET, 10, 188-199 (2019) Article ID: IJARET_10_01_018

7. E. Klimas, M. Lideica, Journal of Property, Planning \& Environmental Law, 10, 240254 (2018) doi: 10.1108/JPPEL-03-2017-0010.2016.05.044

8. M. Marcus, F. Savini, Planning \& Practice, 17, 497-515 (2016) doi: 10.1080/14649357.2016.1210666

9. E. A. Silva, R. A. Acheampong, OECD Environment Working Papers, 94, 51 (2015) doi: 10.1787/5jrp6wgxp09s-en

10. S. Tappert, T. Klöti, M. Drilling, Landscape \& Urban Planning, 170, 69-78 (2018) doi: 10.1016/j.landurbplan.2017.08.016

11. G. Churkina, R. Grote, T. M. Butler, M. Lawrence, Environmental Science \& Policy, 47, 12-17 (2015) doi: 10.1016/j.envsci.2014.10.014

12. C. Frédette, M. Labrecque, Y. Comeau, J. Brisson, Journal of Environmental Management, 246, 526-537 (2019) doi: 10.1016/j.jenvman.2019.06.010

13. X. Zhang, Z. Ni, Y. Wang, S. Chen, B. Xia, Urban Forestry \& Urban Greening, 53, 126700 (2020) doi: 10.1016/j.ufug.2020.126700

14. S. Cepic, J. Tomicevic-Dubljevic, I. Zivojinovic, Urban Forestry \& Urban Greening, 53, 126716 (2020) doi: 10.1016/j.ufug.2020.126716 
15. F. Enssle, N. Kabisch, Environmental Science \& Policy, 109, 36-44 (2020) doi: 10.1016/j.envsci.2020.04.008

16. G. Watts, Urban Forestry \& Urban Greening, 26, 11-17 (2017) doi: 10.1016/j.ufug.2017.05.010

17. H. Saaroni, J. Amorim, J. A. Hiemstra, D. Pearlmutter, Urban Climate, 24, 94-110 (2018) doi: 10.1016/j.uclim.2018.02.001

18. B. A. Norton, A. M. Coutt, S. J. Livesley, R. J. Harris, A. M. Hunter, N. S. G. Willims, Landscape \& Urban Planning, 134, 127-138 (2015) doi: 10.1016/j.landurbplan.2014.10.018

19. R. lan McDonald, Encyclopedia of Biodiversity (Second Edition), 3, 231-244 (2013) doi: 10.1016/B978-0-12-384719-5.00339-7

20. T. K. Patarkalashvili, Annals of Agrarian Science, 15, 187-191 (2017) doi: 10.1016/j.aasci.2017.03.003

21. X. Wang, P. Du, D. Chen, C. Lin, H. Zheng, Journal of Cleaner Production, 274, 122487 (2020) doi: 10.1016/j.jclepro.2020.122487

22. M. S. Boori, K. Choudhary, A. V. Kupriyanov, V. V. Kovelskiy, Data in Brief, 6, 885889 (2016) doi: 10.1016/j.dib.2016.01.056

23. W. van Oijstaeijen, S. van Passel, J. Cools, Journal of Environmental Management, 267, 110603 (2020) doi: 10.1016/j.jenvman.2020.110603

24. M. Tang, Z. Li, F. Hu, B. Wu, Journal of Cleaner Production, 272, 122798 (2020) doi: 10.1016/j.jclepro.2020.122798

25. M. D. Tran, L. Pushkareva, E3S Web of Conferences, 164, 11013 (2020) doi: $10.1051 / \mathrm{e} 3$ sconf $/ 202016411013$

26. I. Polyakova, E. Vasilyeva, Procedia Engineering, 165, 1380-1387 (2016) doi: 10.1016/j.proeng.2016.11.868

27. N. V. Lesyuta, Geography \& Natural Resources, 31(1), 63-67 (2010) doi: 10.1016/j.gnr.2010.03.012 